\title{
Peningkatan Pengetahuan Remaja Tentang Pedoman Umum Gizi Seimbang dengan Permainan Ular Tangga Gizi di SMP PGRI 1 Surakarta
}

\author{
Increasing Adolescent Knowledge About General Guidelines for Balanced Nutrition with the \\ Snakes and Ladders Game of Nutrition in SMP PGRI 1 Surakarta \\ Nastitie Cinintya Nurzihan ${ }^{1)}$, Oktavina Permatasai ${ }^{2)}$ \\ ${ }^{1)}$ Universitas Kusuma Husada Surakarta ${ }^{2}$ Universitas Kusuma Husada Surakarta \\ cnurzihan@gmail.com
}

\begin{abstract}
Permasalahan gizi pada remaja akan menimbulkan dua masalah gizi yaitu gizi kurang dan gizi lebih. Masalah gizi pada remaja tersebut dapat dicegah dengan menggunakan Pedoman Umum Gizi Seimbang (PUGS) dan penerapan PUGS dapat dimulai dengan pemahaman tentang pola hidup sehat yang didukung dengan menerapkan konsumsi makanan yang bergizi seimbang. Pendidikan gizi di lingkungan sekolah dapat memberikan dukungan yang positif terhadap pengetahuan, sikap dan tendakan remaja. Pendidikan mengenai gizi seimbang perlu disosialisasikan mengingat masih banyak remaja yang belum paham tentang gizi seimbang pada remaja di SMP PGRI 1 Surakarta berdasarkan studi pendahuluan. Peningkatan pengetahuan remaja akan gizi seimbang dapat dilakukan dengan memberikan edukasi. Edukasi yang efektif adalah dengan pendekatan metode ular tangga gizi yang merupakan alat permainan edukatif yang dapat mendorong minta remaja tentang gizi seimbang. Pengabdian ini bertujuan untuk memberikan edukasi kepada remaja akan pentingnya konsumsi gizi seimbang untuk menunjang prose pertumbuhan pada masa remaja. Kegiatan yang dilakukan dengan proses penyuluhan dengan metode ulartangga gizi sehingga dapat meningkaatkan pengetahuan, pemahaman dan kesadaran tentang konsumsi gizi seimbang.
\end{abstract}

Keywords: "edukasi" "pugs" "remaja" "ular tangga gizi"

\section{PENDAHULUAN}

Ketidak seimbangan antara makanan yang dikonsumsi dengan kebutuhan pada remaja akan menimbulkan dua masalah gizi yaitu gizi kurang dan gizi lebih. Remaja yang merupakan aset bangsa dalam terciptanya generasi yang baik di masa yang akan datang. Masalah gizi kurang pada remaja disebabkan beberapa faktor diantaranya pola makan yang tidak seimbang, perubahan psikososial dan kebutuhan remaja yang meningakat (Adnani dan Wirjatmadi, 2013). Hal tersebut dapat dicegah dengan menerapkan gizi seimbang yang tertuang pada Pedoman Umum
Gizi Seimbang (PUGS). PUGS dapat dimulai dengan pemahaman tentang pola hidup sehat yang didukung dengan praktik (Kemenkes, 2014; Sulistyoningsih, 2012). Penerapan tersebut dilakukan dengan memberikan pengetahuan melalui pendidikan tentang gizi seimbang yang dapat mencegah masalah gizi pada remaja (Supariasa, 2013). Pendidikan yang dilakukan di sekolah dapat memberikan pengaruh positif terhadapat pengetahuan, sikap dan tindakan (Kostanjevec et al., 2011). Salah satu metode pendidikan yang umum dilakukan adalah dengan memberikan pendekatan melalui 
penyuluhan yang bertujuan untuk menyampaikan pesan atau informasi sehingga dapat diterima dan dipahami dengan baik oleh audien. Namun pendekatan dengan metode penyuluhan sering dianggap tidak efektif karena materi yang rinci disampaikan mudah terlupakan (Notoatmodjo, 2015). Salah satu cara yang efektif memberikan informasi adalah dengan membuat permainan sederhana agar pesan dan informasi yang disampaikan bisa dipahami oleh remaja, misalnya permainan ular tangga. Permainan ular tangga memenuhi beberapa syarat sebagai alat permainan edukatif diantaranya tahan lama, mendorong remaja bermain tradisional dan mudah didapat (Rinaldi, 2019). Secara psikologis, ular tangga terbukti dapat meningkatkan kemampuan untuk berinteraksi dengan kehidupan social (Chabib et al., 2017). Beberapa penelitian juga menyebutkan bahwa simulasi permaianan ular tangga efektif dalam meningkatkan pengetahuan tentang materi kesehatan. Oleh karena itu, permainan ular tangga diharapkan dapat meningkatkan dan pengetahuan juga sikap tentang gizi seimbang agar generasi muda khususnya remaja untuk mendapatkan kesehatan yang optimal.

\section{METODE}

1) Lokasi dan Waktu Kegiatan

Kegiatan penyuluhan dan gizi seimbang pada remaja melalui permainan ular tangga di SMP PGRI 1 Surakarta pada Juli 2019

2) Metode, Alat dan Bahan a. Metode pembelajaran

i. Ceramah

Metode ini digunakan sebagai pengantar untuk memberikan penekanan pengetahuan tentang gizi seimbang dan konsumsi makanan yang baik

ii. Diskusi/Tanya Jawab

Metode ini digunakan baik pada saat dilangsungkannya

penyuluhan atau pada saat setelah penyuluhan yang memungkinkan remaja memahami tentang gizi seimbang dan juga dapat menanyakan secara langsung mengenai hal-hal yang belum dimengerti pada saat penyampaian penyuluhan tersebut

iii. Demonstrasi

Demonstrasi dilakukan dengan mempraktikkan penggunaan alat bantu dalam penyuluhan yaitu ular tangga gizi sebagai media dalam memberikan pengetahuan agar mudah dipahami oleh remaja

\section{3) Tahapan Kegiatan}

a. Kegiatan pengabdian kepada masyarakat dimulai dengan membuat perencanaan yang dibuat dalam proposal kegiatan pengabdian masyarakat. Pembuatan proposal dilakukan pada minggu bulan Maret 2019

b. Perbaikan proposal setelah mendapat masukan dan revisi dari LPPM STIKes Kusuma Husada

c. Pertemuan dengan pihak sekolah dengan perwakilan Prodi Sarjana Gizi. Kegiatan ini difokuskan pada pemahaman bahwa kegiatan penyuluhan gizi seimbang sangat penting dilakukan 
mengingat rendahnya pemahaman remaja mengenai pemilihan makanan yang baik dikonsumsi. Oleh karena itu, pemberian pengetahuan mengenai gizi seimbang dapat meningkatan pengetahuan dalam pemilihan makanan untuk para remaja

d. Koordinasi dengan wali kelas mengenai waktu dan tempat penyuluhan gizi seimbang yang akan dilaksanakan. Selain itu juga mengkoordinasi materi yang akan disampaikan, jika tidak ada perubahan atau tambahan dari wali kelas maka akan ditetapkan waktu kegiatan pengabdian masyarakat

e. Persiapan alat dan materi

Persiapan alat bantu yaitu ular tangga gizi dan materi penyuluhan akan dilakukan pada bulan Maret - Agustus 2019 di Prodi Sarjana Gizi STIKes Kusuma Husada Surakarta. Pada tahap ini maka koordinator beserta anggota tim akan menyusun satuan acara penyuluhan dan mempersiapkan alat yang telah ditetapkan dalam menunjang proses penyuluhan tersebut

f. Pelaksanaan pengabdian kepada masyarakat

Pelaksanaan pengabdian masyarakat berupa penyuluhan tentang gizi seimbang yang akan dilakukan sesuia dengan kesepakatan dengan pihak sekolah. Kegiatan diawali dari pengarahan dari koordinator peyuluhan kepada anggota tim. Kegiatan berupa penyuluhan tentang gizi seimbang dengan media permainan ular tangga gizi sehingga dapat memudahkan pemahaman remaja dengan materi yang disampaikan

g. Monitoring dan evaluasi

Setelah dilakukan proses pengajaran dan penyuluhan tentang gizi seimbang maka akan dilakukan monitoring dan evaluasi berupa kunjungan ke sekolah dimana remaha diberikan penyuluhan mengenai gizi seimbang. Pada proses monitoring kunjungan ke sekolah makankoordinator beserta tim anggota akan mengevaluasi tingkat pengetahuan dalam memilih makanan yang baik dan seimbang

h. Penyusunan laporan kegiatan pengabdian masyarakat

Kegiatan pengabdian masyarakat yang telah dilakukan akan disusun menjadi laporan kegiatan pengabdian masyarakat dan akan dilakukan pada bulan Agustus 2019

\section{HASIL DAN PEMBAHASAN \\ 1) HASIL}

Hasil

pelaksanaan

penyuluhan, pelaksanakan dan evaluasi permaianan ular tangga gizi dilakukan selama beberapa hari yang diikuti oleh siswa kelas 7 - 9 yang berjumlah 53 orang, dari hasil pretest dan posttest menujukkan terjadinya peningkatan pengetahuan siswa dalam pemahaman tentang gizi seimbang seperti 
Pedoman Umum Gizi Seimbang (PUGS). Rangkaian kegiatan penyuluhan pada siswa SMP PGRI 1 Surakarta mendapatkan respon yang cukup baik dari siswa maupun pihak sekolah sendiri. Kegiatan pretest tentang gizi seimbang dilakukan sebelum penyuluhan dan permainan ular tangga gizi dilakukan. Hasil pretest tersebut menunjukkan bahwa masih banyak siswa yang memiiki pengetahuan yang kurang tentang gizi seimbang.

Setelah dilakukan kegiatan penyuluhan dan permainan ular tangga gizi terjadi peningkatan pengetahuan dan pemahaman tentang gizi seimbang untuk remaja. Siswa lebih bisa memahami tentang gizi seimbang melalui permainan ular tangga yang berisi tentang informasi 13 poin dalam PUGS.

Sasaran yang dilibatkan dalam kegiatan ini adalah siswa siswi yang berjumlah 60 orang. Pada pelaksaan kegiatan jumlah siswa yang hadir sebanyak 53 orang. Angka Kehadiran Peserta (AKP) dengan perhitunga sebagai berikut

$$
\begin{aligned}
& \text { AKP } \\
& =\frac{\text { uah a ag ha }}{\text { uah uuha }} 100 \% \\
& A K P=\frac{53}{60} \quad 100 \%=88.3 \% \\
& \text { Berdasarjan hasil pengamatan } \\
& \text { selama pelaksanaan dan } \\
& \text { pemantauan yang telah } \\
& \text { dilaksanakan diperoleh hasil } \\
& \text { sebagai berikut: }
\end{aligned}
$$

a. Siswa telah meningkatkan pengetahuan tentang gizi seimbang yang terlihat dari hasil tes yang diperoleh sebleum pelaksaan kegiatan dan setelah kegiatan. Nilai pengetahuan tersebut diperoleh sebelum kegiatan penyuluhan cukup rendah dengan nilai rata-rata 52 dan setelag kegiatan mengalami peningkatan menjadi 81 dari nilai maksimun 100 .

Grafik 1:

Nilai Rata-Rata Siswa

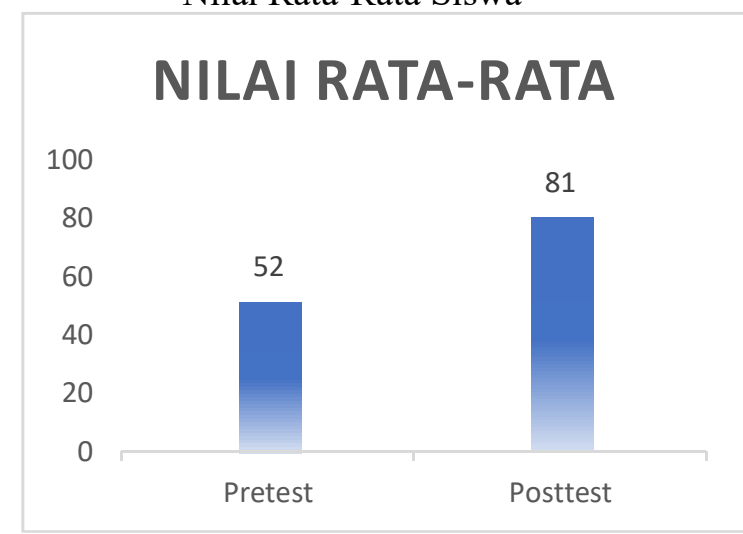

Sumber: Data Pribadi, diolah (2019)

b. Permainan ular tangga digizi dilakukan dengan antusiasme cukup tinggi dari siswa. Pada kegiatan ini, siswa tiap kelas dibagi menjadi 4 kelompok yang terdiri dari $4-5$ orang siswa. Setiap kelompok mendapatkan satu set permainan ular tangga yang berisi satu alas permainan, dadu dan bidak/pion tiap anggota kelompok. Tiap orang bermain secara begilir dan 
jika anggota berhenti di kotak tertentu, maka pendamping permainan melakukan penjelasan mengenai isi dari ular tangga tersebut.

\section{2) PEMBAHASAN}

Pengetahuan tentang gizi seimbang pada remaja sesuai dengan kondisi remaja yang tertuang dalam Pedoman Umum Gizi Seimbang (PUGS) sehingga materi pengetahuan dan permainan ular tangga gizi diperhatikan dengan baik oleh para siswa. Dengan kegiatan tersebut telah mendorong siswa untuk lebih memperhatikan makanan yang dikonsumsi dan jenis bahan makanan yang ditingkatkan serta yang dibatasi untuk dikonsumsi oleh para remaja.

Kegiatan pengabdian masyarakat ini yang didasarkan dari hasil penelitian Saputri, dkk (2012), Amelia (2010), Nachiappan et al. (2014) yang hasilnya terdapat peningkatan pengetahuan setelah pemberian intervensi dengan media permainan ular tangga. Menurut Notoatmodjo (2015) pengetahuan merupakan hasil penginderaan manusia atau hasil dari tahu seseorang setelah melakukan penginderaan terhadap suatu objek tertentu. Penginderaan terjadi melalui panca indera manusia, yakni indera penglihatan, penciuman, rasa, dan raba, sebagian besar pengetahuan manusia diperoleh melalui mata dan telinga. Saat memainkan ular tangga yang sebagian besar yang digunakan adalah mata dan telinga, dimana dalam bermain siswa melihat gambar dan membaca materi yang terdapat di media ular tangga, kemudian siswa yang lain mendengarkan pernyataan yang dibacakan dan memperhatikan penjelasan yang dijelaskan oleh tim pengabdian masyarakat. Penggunaan media permainan ular tangga dalam kegiatan ini membuat siswa mendapatkan pengetahuan dengan cara yang menyenangkan, yakni belajar sambil bermain.

Ular tangga adalah salah satu media yang digunakan dalam kegiatan belajar mengajar dimana permainan ular tangga dapat memuat informasi informasi penting yang terdapat di petak - petaknya. Hal ini sangat menyenangkan sehingga remaja tertarik untuk belajar sambil bermain (Novarina, 2010). Permainan ular tangga dapat merangsang seseorang untuk mengembangkan kemampuan kognitif, moral, mental emosional dan social, serta psikomotor. Penyuluhan gizi didukung oleh media yang disesuaikan dengan sasaran yang akan dituju (Notoatmodjo, 2015).

\section{KESIMPULAN}

Pelaksanaan penyuluhan dan permainan ular tangga gizi mengenai peningkatan 
pengetahuan remaja tentang gizi seimbang mendapatkan respon yang baik oleh siswa di SMP PGRI 1 Surakarta. Kehadiran siswa dalam kegiatan ini mencapai $88,6 \%$ dan dapat meningkatan pengetahuan gizi seimbangan dengan nilai rata-rata 52 menjadi 81 dari nilai total 100. Kegiatan yang diberikan dapat meningkatkan pengetahuan gizi seimbang remaja dan dapat meningkatkan derajat kesehatannya

\section{SARAN}

Dari hasil kegiatan penyuluhan dan permainan ular tangga gizi tentang gizi seimbang remaja, maka disarankan:

1. Diharapkan adanya kegiatan penyuluhan gizi secara berkelanjutan

2. Perlu pengetahuan lebih lanjut mengenai jenis makanan yang boleh dikonsumsi oleh para remaja

3. Himbauan membawa sarapan bagi siswa agar konsumsi makanan dapat terpenuhi

\section{REFERENSI}

Adnani H \& Wirjatmadi. (2013). Ilmu Kesehatan Masyarakat. Yogyakarta: Mulia Medika

Amelia, C. (2010). Efektivitas Permainan Ular Tangga untuk Meningkatkan Pengetahuan tentang Bahaya Rokok Siswa Kelas VII dan VIII SMP Ma'aruf $\mathrm{Nu}$ Tegal. Skripsi: Universitas Negeri Semarang

Chabib M, Ery T.D \& Dedi Kusmandi. (2017) Efektivitas Pengembangan Media Permainan Ular Tangga Sebagai Sarana Belajar Tematik SD.
Jurnal Pendidikan: Teori, Penelitian dan Pengembangan Vol, 2 No $7 \mathrm{Hlm}$ 910-918

Kementerian Kesehatan RI. (2014). Pedoman Gizi Seimbang (Pedoman Teknis Bagi Petugas dalam Memberikan Penyuluhan Gizi Seimbang). Jakarta: Direktorat Jenderal Bina Gizi dan Kesehatan Ibu dan Anak

Kostanjevec, S., Jerman, J., Koch, V. (2011). The Effects of Nutrition Education on 6th Graders Knowledge of Nutrition in Nine-year Primary Schools in Slovenia. Eurasia Journal of Mathematics, Science \& Technology Education, 7(4), 243-252

Nachiappan, S., Rahman, N.A. Andi H., Fatimah, Z.M., (2014). Snake and Ladder Games in Cognition Development on Students with Learning Difficulties. Jurnal American Research Institute, Vol.3, No.2: 217-229.

Notoatmodjo, Soekidjo. (2015). Pendidikan dan Perilaku Kesehatan (Edisi Revisi). Jakarta: PT. Rineka Cipta

Notoatmodjo. Soekidjo. (2015). Promosi Kesehatan dan Perilaku Kesehatan, Jakarta: Rineka Cipta.

Novarina, D (2010), Penggunaan Permainan Ular Tangga Untuk Meningkatkan Kemampuan Kognitif Anak dalam Memahami Konsep Bilangan di TK. Skripsi, Universitas Negeri Malang

Saputri, Lila O., Kristiawati, Ilya K. (2012). Peningkatan Pengetahuan 
dan Sikap dalam Pemilihan Jajanan Sehat Menggunakan Alat Permainan Edukatif Ular Tangga. Skripsi: Universitas Airlangga.
Sulistyoningsih, H. (2012). Gizi untuk Kesehatan Ibu dan Anak. Yogyakarta: Graha Ilmu.

Supariasa D.N. (2013). Pendidikan dan Konsultasi Gizi. Jakarta: EGC 